\title{
Spirulina platensis Geitler sebagai Fikoremediator Logam Berat Pb Skala Laboratorium
}

\section{Muhammad Sindhunata Prambodo, Riche Hariyati, dan Tri Retnaningsih Soeprobowati}

\author{
Laboratorium Ekologi dan Biosistematik \\ Departemen Biologi, Fakultas Sains dan Matematika, Universitas Diponegoro, Semarang \\ Jln Prof. Soedarto, SH,Semarang,50275, Telp: (024)7474754; Fax (024) 76480923 \\ Email : m.sindhunata.p@gmail.com; trisoeprobowati@live.undip.ac.id; riche.hariyati@gmail.com
}

\begin{abstract}
Industrial waste contributes the heavy metals pollution in the environment, especially in the water. One of the heavy metals that pollute the environment is lead $(\mathrm{Pb})$. Lead is a substance that is harmful to organisms, especially humans, both adults and children. Solutions to tackle $\mathrm{Pb}$ pollution isby remediation process. Physical and chemical remediation methods usually costly and ineffective. One of the alternative methods which is used is the bioremediation uses microalgae or called as phycoremediation. One of microalgae which is used as agents of phycoremediation is Spirulina platensis Geitler because it's easily cultured and it's abundant in nature. This study aims to assess the population growth and the percentage reduction of $\mathrm{Pb}$ after inoculated with the use of Spirulina platensis Geitler. The method which is to cultivate S. platensis Geitler in brackish watermedia with a salinity of 15 ppt which have been added $\mathrm{Pb}$ with a concentration of $1 \mathrm{mg}, 3 \mathrm{mg}$, and $5 \mathrm{mg}$ for 8 days and observed the population and the percentage reduction of $\mathrm{Pb}$ heavy metals. Environmental factors such as temperature, salinity, $\mathrm{pH}$, light intensity are conditioned to remain stable. After 8 days of research, study was able to reduce $\mathrm{Pb}$. Each treatment has different concentrations decrease. Treatment $\mathrm{Pb} 1 \mathrm{mg}$ of 0.949 into $0.603 \mathrm{mg} / \mathrm{L} ; \mathrm{Pb} 3 \mathrm{mg}$ of 2.894 to $2.46 \mathrm{mg} / \mathrm{L}$; and $\mathrm{Pb} 5 \mathrm{mg}$ of 4.88 to $4.31 \mathrm{mg} / \mathrm{L}$, with each percentage decline of $36 \%, 15 \%$ and $12 \%$. The $\mathrm{Pb} 3 \mathrm{mg}$ treatment has higher cell population $(129.367 \mathrm{cell} / \mathrm{ml})$ than control $(106.600 \mathrm{cell} / \mathrm{ml})$ while $1 \mathrm{mg}$ and $5 \mathrm{mg}$ treatment has 93.700 cell / $\mathrm{ml}$ and 93.500 cell / $\mathrm{ml}$.
\end{abstract}

Keywords: Spirulina platensis, phycoremediation, waste, lead.

\begin{abstract}
Abstrak
Limbah industri berkontribusi dalam pencemaran logam berat pada lingkungan khususnya perairan. Salah satu logam berat yang mencemari lingkungan adalah timbal $(\mathrm{Pb})$. Timbal merupakan senyawa yang berbahaya bagi organisme khususnya manusia, baik dewasa maupun anak-anak. Solusi untuk menanggulangi pencemaran $\mathrm{Pb}$ salah satunya yaitu dengan melakukan proses remediasi. Metode remediasi secara fisik dan kimia memerlukan biaya yang mahal dan tidak efektif, salah satu metode alternatif yang digunakan adalah dengan bioremediasi dengan menggunakan mikroalga atau disebut dengan fikoremediasi. Mikroalga yang digunakan sebagai agen fikoremediasi adalah Spirulina platensis Geitler karena mudah dikultur dan memiliki jumlah yang melimpah di alam. Penelitian ini bertujuan untuk mengkaji pertumbuhan populasi dan persentase penurunan logam berat $\mathrm{Pb}$ setelah diinokulasikan dengan menggunakan Spirulina platensis Geitler. Metode yang digunakan adalah mengkultivasi Spirulina platensis Geitler dalam media air payau salinitas $15 \mathrm{ppt}$ yang telah diberi $\mathrm{Pb}$ dengan konsentrasi $1 \mathrm{mg}, 3 \mathrm{mg}$, dan $5 \mathrm{mg}$ selama 8 hari dan diamati populasinya serta persentase penurunan logam berat $\mathrm{Pb}$. Setiap perlakuan memiliki penurunan konsentrasi yang berbeda. Perlakuan $\mathrm{Pb} 1 \mathrm{mg}$ dari 0,949 menjadi $0,603 \mathrm{mg} / \mathrm{L} ; \mathrm{Pb} 3 \mathrm{mg}$ dari 2,894 menjadi 2,46 $\mathrm{mg} / \mathrm{L}$; dan $\mathrm{Pb} 5 \mathrm{mg}$ dari 4,88 menjadi 4,31 mg/L, dengan persentase penurunan masing-masing sebesar 36\%, 15\%, dan 12\%. Perlakuan Pb 3 mg memiliki jumlah sel yang lebih tinggi (129.367 sel $/ \mathrm{ml})$ dari control $(106.600 \mathrm{sel} / \mathrm{ml})$, sedangkan perlakuan $\mathrm{Pb} 1 \mathrm{mg}$ dan $\mathrm{Pb} 5 \mathrm{mg}$ memiliki jumlah sel masing-masing sebesar $93.700 \mathrm{sel} / \mathrm{ml}$ dan 93.500 $\mathrm{sel} / \mathrm{ml}$.
\end{abstract}

Kata kunci: Spirulina platensis, fikoremediasi, limbah, timbal 


\section{PENDAHULUAN}

Pencemaran air adalah masuknya atau dimasukkannya makhluk hidup, zat, energi, dan atau komponen lain ke dalam air oleh kegiatan manusia, sehingga kualitas air turun sampai ketingkat tertentu yang menyebabkan air tidak dapat berfungsi sesuai dengan peruntukannya (PP No.82 tahun 2001). Salah satu pencemaran air yaitu pencemaran logam berat timbal $(\mathrm{Pb})$.Timbal terdapat dalam limbah cair industri yang pada proses produksinya menggunakan timbal, seperti industri pembuatan baterai, industri cat, dan industri keramik.

Hasil penelitian Naria (1999) menemukan bahwa pada kandungan timbal tanaman pada umur 26 hari setelah tanam adalah $1,98 \mathrm{mg} / \mathrm{L}$ untuk bayam, 2,72 mg/L untuk selada, dan $1,80 \mathrm{mg} / \mathrm{L}$ untuk kangkung. Tanaman tersebut setiap hari disiram dengan air sungai yang mengandung timbal rata-rata $0,063 \mathrm{mg} / \mathrm{L}$. Masuknya timbal ke dalam tanaman tersebut berarti munculnya resiko kesehatan pada manusia ketika mengkonsumsi tanaman tersebut.

Usaha remediasi untuk mengatasi masalah pencemaran logam berat bisa dilakukan secara fisik, kimia, dan biologi. Banyaknya kendala dan biaya yang mahal menyebabkan manusia menggunakan cara biologis sebagai salah satu alternatif penanganan limbah logam berat. Remediasi secara biologis dinamakan bioremediasi. Bioremediasi merupakan penggunaan mikroorganisme yang telah dipilih untuk ditumbuhkan pada polutan tertentu sebagai upaya untuk menurunkan kadar polutan tersebut (Priadie, 2012).

Fikoremediasi merupakan salah satu proses bioremediasi dengan menggunakan mikroalga (Rao et al., 2011). Salah satu mikroalga yang dapat meremediasi logam berat adalah Spirulina platensis. Penelitian yang dilakukan Maulana (2013) menyebutkan bahwa semakin besar populasi $S$. platensis maka semakin besar penyerapan logam $\mathrm{Cu}$ oleh sel. Penelitian yang dilakukan Soeprobowati dan Hariyati (2014) menyebutkan bahwa Spirulina mampu untuk mengikat logam berat (konsentrasi tinggi) pada ion $\mathrm{Cr}^{+3}, \mathrm{Cu}^{+2}, \mathrm{Cd}^{+2}$, dan $\mathrm{Pb}^{+2}$.

Berdasarkan fakta dan kondisi tersebut, makaperlu dilakukan penelitian untuk mengetahui bagaimana pengaruh $\mathrm{Pb}$ terhadap pertumbuhan populasi $S$. platensis. Hasil penelitian inidiharapkan dapat memberikan manfaat yang positif bagi ilmu pengetahuan dan pemerintah. Hasil positif dari penelitian ini bisa dijadikan pedoman bagi penelitian selanjutnya, agar mendapatkan hasil yang lebih baik khususnya pada efisiensi proses bioremediasisehingga dapat membantu pihak pemerintah dalam melakukan proses pengawasan dan penanggulangan limbah logam berat, khususnya timbal atau $\mathrm{Pb}$ yang masih terjadi di lingkungan.

\section{BAHAN DAN METODE}

Penelitian dilakukan di Laboratorium Ekologi dan Biosistematik, Jurusan Biologi Fakultas Sains dan Matematika UNDIP, bulan November Desember 2013.

Bahan yang digunakan dalam penelitian ini antara lain : biakan fitoplankton Spirulina platensis, air laut salinitas 15 ppt, aquades, logam berat $\mathrm{PbNO}_{3}$, dan pupuk Walne.

Alat yang digunakan dalam penelitian ini antara lain : toples kaca, $\mathrm{pH}$ meter, aerator, lampu neon, termometer, mikroskop, Sedgewick Rafter Counting Cell, refraktometer, luxmeter, dan DO meter.

\section{Penyiapan bibit Spirulina platensis}

Bibit awal Spirulina platensis yang digunakan dalam penelitian ini berasal dari laboratorium Balai Besar Pengembangan Budidaya Air Payau (BBPBAP) Jepara. Populasi awal Spirulina platensis sebagai inokulum adalah $10.000 \mathrm{sel} / \mathrm{ml}$. Stok kultur dihitung populasinya menggunakan mikroskop perbesaran 10x dengan Sedgewick RafterCounting (SRC) dengan rumus: $\mathrm{N}_{1}(\mathrm{sel} / \mathrm{ml})$ $=\{(\mathrm{C} \times 1000) /(\mathrm{A} \times \mathrm{F})\} / \mathrm{R}$ dengan :

$$
\begin{aligned}
\mathrm{N}_{1} & =\text { Kelimpahan Sel } \\
\mathrm{C} & =\text { Jumlah sel terhitung } \\
\mathrm{A} & =\text { Konstanta }(3,14) \\
\mathrm{R} & =\text { Pengenceran } \\
\mathrm{F} & =\text { Jumlah bidang pandang }
\end{aligned}
$$

Setelah diketahui populasi Spirulina platensis pada stok kultur kemudian ditentukan volume inokulum dari stok kultur yang dibutuhkan untuk 
kultur 1 liter. Dihitung menggunakan rumus : $\mathrm{V}_{1} \mathrm{~N}_{1}=\mathrm{V}_{2} \mathrm{~N}_{2}$ dengan :

$\mathrm{V}_{1}=$ Volume inokulum yang diinginkan

$\mathrm{V}_{2}=$ Volume medium kultur $(1.000 \mathrm{ml})$

$\mathrm{N}_{1}=$ Kelimpahan stok ( $\left.\mathrm{sel} / \mathrm{ml}\right)$

$\mathrm{N}_{2}=$ Kelimpahan sel yang diinginkan (10.000)

\section{Pengukuran Faktor Abiotik}

Penelitian dilakukan selama 8 hari. Faktor eksternal: salinitas, $\mathrm{pH}$, suhu, DO dan intensitas cahaya dijaga selalu setiap harinya. Jumlah populasi Spirulina platensis dihitung setiap harinya dengan rentang waktu 24 jam hingga delapan hari penelitian. Pengambilan sampel untuk analisis konsenterasi $\mathrm{Pb}$ di dalam medium dan $S$. platensis dilakukan pada hari ke-0 dan ke-7..

\section{HASIL DAN PEMBAHASAN}

Suhu kultur saat penelitian rata-rata $28{ }^{\circ} \mathrm{C}$. Suhu ini tidak membahayakan sel $S$. platensis karena masih dalam kisaran suhu optimal pertumbuhan S. platensis.Menurut Isnansetyo dan Kurniastuty (1995), Spirulina platensis dapat tumbuh dengan baik pada kisaran suhu antara 25$35{ }^{\circ} \mathrm{C}$. Mikroalga memiliki berbagai enzim yang digunakan untuk proses fotosintesis. Bagian protein enzim yang disebut apoenzimsangat menentukan fungsi biokatalisator dari enzim. Bagian ini akan rusak pada suhu terlampau panas atau bersifat termolabil(Bergmeyer, 1984).

Derajat keasaman $(\mathrm{pH})$ kultur saat penelitian rata-rata berada pada angka 7. Isnansetyo dan Kurniastuty (1995) menerangkan bahwa $\mathrm{pH}$ yang baik untuk pertumbuhan berkisar antara 7,2 - 9,5. Menurut Suantika dan Hendrawandi (2009), kenaikan nilai $\mathrm{pH}$ disebabkanoleh bertambahnya ion hidroksil dalam kultur akibatasimilasi $\mathrm{CO}_{2}$ dan $\mathrm{HCO}^{3-}$ oleh S. platensis. Bertambahnya periode kultur mengakibatkan penurunan jumlah bikarbonat dan terjadi akumulasi karbonat dalam kultur. Akumulasi karbonat inilah yang akan meningkatkan nilai $\mathrm{pH}$ pada kultur karena karbonat merupakan senyawa paling basa diantara senyawa $\mathrm{C}$ lainnya $\left(\mathrm{HCO}^{3-}\right.$ dan $\left.\mathrm{CO}_{2}\right)$. Penelitian menemukan bahwa $\mathrm{pH}$ maksimum saat penelitian sebesar 8, tidak melebihi batas maksimal yang dapat mengganggu pertumbuhan sel $S$. platensis.

Salinitas kultur saat penelitian berkisar 15-17 ppt. Menurut Hariyati (2008), salinitas yang optimal untuk pertumbuhan Spirulina platensis adalah berkisar antara 15 - 20 ppt. Pertumbuhan sel saat penelitian mengalami peningkatan dengan ditandai oleh kenaikan jumlah sel. Hal ini menandakan bahwa $S$. platensis dapat menyesuaikan diri dengan kondisi salinitas kultur. Menurut Hariyati (2008), kebanyakan alga memperlihatkan terjadinya hambatan proses fotosintesis setelah dipindahkan pada medium dengan salinitas yang lebih tinggi atau tekanan osmotik yang lebih tinggi.

Spirulina platensis merupakan organisme fotoautotrof yang memerlukan cahaya untuk melakukan fotosintesis. Saat penelitian warna kultur semakin lama semakin berwarna hijau pekat. Hal ini menandakan bahwa terjadi proses fotosintesis yang baik bagi pertumbuhan sel $S$. platensis. Menurut Mohanty et al., (1997), Spirulina mempunyai kemampuan untuk berfotosintesis dan mengubah energi cahaya menjadi energi kimia dalam bentuk karbohidrat. Dalam penelitian ini, sumber cahaya berasal dari lampu berdaya 40 watt yang menghasilkan energi sebesar 2800 lux.Soong (1980) menyebutkan bahwa Spirulina dapat tumbuh optimal dengan intensitas cahaya sebesar 1500-3000 lux.

Kehidupan S. platensis juga ditunjang oleh ketersediaan nutrisi, baik mikro maupun makro. Menurut Vonshak et al., (2004) dan Sanchez-Luna et al., (2006) kualitas kandungan nutrien Spirulina platensis berkaitan dengan komposisi nutrien di media kultur dan parameter kualitas airnya. Media walne yang mengandung makronutrien dan mikronutrien yang lengkap bagi mikroalga, digunakan pada penelitian ini sebagai sumber nutrien bagi Spirulina platensis karena mengandung nutrisi yang lengkap.Mikronutrien berupa $\mathrm{Fe}, \mathrm{Mo}, \mathrm{Cu}, \mathrm{Ca}, \mathrm{Mn}, \mathrm{Zn}$, dan Co serta makronutrien $\mathrm{N}, \mathrm{P}, \mathrm{S}, \mathrm{K}, \mathrm{Si}$ dan Ca dibutuhkan untuk menunjang pertumbuhan $S$. platensis.

\section{Pertumbuhan Spirulina platensis}

Pertumbuhan $S$. platensis diamati selama 8 hari karena berdasarkan penelitian tahun 2008 yang dilakukan Widianingsih et al., pertumbuhan $S$. platensis mengalami fase akhir (fase stasioner) dalam kurun waktu 6 hari. Penelitian dilakukan 8 hari karena peneliti ingin mengetahui perubahan jumlah sel setelah $S$. platensis mengalami fase 
stasioner. Pertumbuhan sel $S$. platensis dapat dilihat pada Gambar 1.

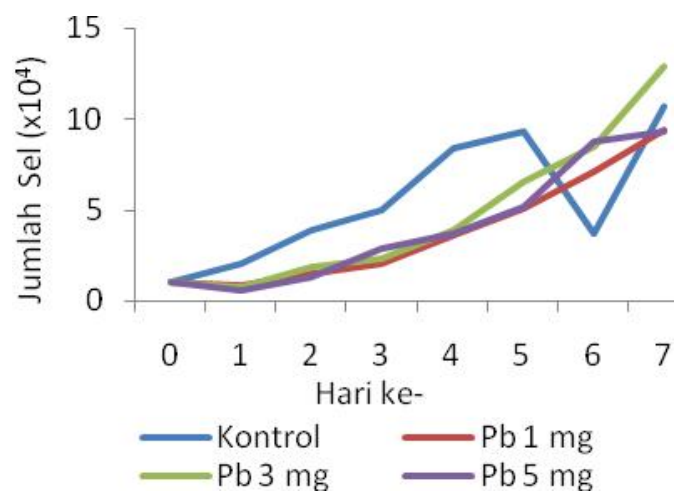

Gambar 1. Grafik rata-rata populasi Spirulina platensis Geitler.

Pada Gambar 1 di atas, terjadi kenaikan jumlah sel pada kontrol dan semua perlakuan. Populasi yang mengalami kenaikan jumlah sel tertinggi di akhir penelitian yaitu perlakuan $\mathrm{Pb} 3$ mg, sedangkan jumlah sel terendah dialami oleh kontrol yang tidak ditambahkan logam $\mathrm{Pb}$. Kenaikan jumlah sel juga terjadi pada perlakuan logam $\mathrm{Pb} 1 \mathrm{mg}$ dan $5 \mathrm{mg}$.

Siklus hidup mikroalga terdiri dari lima fase, antara lain fase lag, eksponensial, deklinasi, stasioner, dan kematian. Fase lag atau adaptasi dimulai diawal pertumbuhan. Menurut Edhy et al., (2003), selama fase ini pertambahan massa atau pertambahan jumlah sel belum begitu terjadi, sehingga kurva fase ini umumnya mendatar.

Pada penelitian, kontrol mengalami fase adaptasi yang lebih cepat dari perlakuan $\mathrm{Pb} 1 \mathrm{mg}$, $\mathrm{Pb} 3 \mathrm{mg}$, dan $\mathrm{Pb} 5 \mathrm{mg}$. Hal ini ditandai dengan pertumbuhan jumlah sel di hari ke-1 yang mencapai dua kali lipat, dari 10.000 sel $/ \mathrm{ml}$ menjadi $19.900 \mathrm{sel} / \mathrm{ml}$. Penelitian yang dilakukan Widianingsih et al., (2008), memperlihatkan kesamaan pada kontrol, yaitu fase pertumbuhan $S$. platensis dimulai sejak hari ke-0.

Fase adaptasi yang lebih cepat pada kontrol menandakan bahwa kondisi lingkungan kontrol lebih baik dari ketiga perlakuan lain yang ditambahkan logam berat. Menurut Aksu dan Donmez (2006) mikroalga mampu secara selektif menyerap dan menyerap logam dari media cair dan mengakumulasi logam tersebut dalam selnya. Penambahan logam berat pada perlakuan $\mathrm{Pb} 1 \mathrm{mg}$, $\mathrm{Pb} 3 \mathrm{mg}$, dan $\mathrm{Pb} 5 \mathrm{mg}$ membuat sel-sel S. platensis melakukan adaptasi sehingga memerlukan waktu lebih lama pada fase hidupnya. Siswati et al., (2011) menyebutkan bahwa dinding sel jasad hidup baik prokariotik maupun eukariotik tersusun dari polisakarida, salah satu polisakarida yang terkandung dalam dinding sel adalah senyawa alginate yang mempunyai ikatan ionik dengan mekanisme sebagai berikut :

$$
2 \mathrm{NaAlg}+\mathrm{Pb}^{2} \mathrm{~Pb}(\mathrm{Alg})^{2}+2 \mathrm{Na}
$$

Berdasarkan reaksi di atas, polisakarida berupa senyawa alginat yang menyusun dinding sel $S$. platensis, berikatan dengan logam berat $\mathrm{Pb}$. Logam berat $\mathrm{Pb}$ dan nutrien kultur bersaing untuk dapat berikatan dengan permukaan sel S. platensis yang berupa senyawa alginate.

Fase adaptasi sel S. platensis terhadap logam berat terjadi pada perlakuan selain kontrol. Hal ini dapat dilihat dari pertambahan jumlah sel perlakuan $\mathrm{Pb} 1 \mathrm{mg}, \mathrm{Pb} 3 \mathrm{mg}$, dan $\mathrm{Pb} 5 \mathrm{mg}$ dihari ke-2 penelitian, yang merupakan awal fase eksponensial. Pertambahan jumlah sel tersebut antara lain : perlakuan $\mathrm{Pb} 1 \mathrm{mg}$ naik dari 8.100 menjadi $14.983 \mathrm{sel} / \mathrm{ml}$; perlakuan $\mathrm{Pb} 3 \mathrm{mg}$ naik dari 7.420 menjadi $18.333 \mathrm{sel} / \mathrm{ml}$; dan perlakuan 5 $\mathrm{mg}$ naik dari 5.277 menjadi $12.683 \mathrm{sel} / \mathrm{ml}$.

Pertambahan jumlah sel di atas menandakan bahwa fase hidup $S$. platensis sudah memasuki fase eksponensial.Gambar 1 memperlihatkan bahwa fase eksponensial terjadi hingga hari ke-7 penelitian. Kontrol mencapai fase puncak dengan waktu paling cepat yaitu lima hari. Penelitian Widianingsih et al., (2008) menyatakan bahwa fase puncak dicapai setelah 4,5 hari penelitian atau lebih cepat 12 jam daripada kontrol pada penelitian ini. Penyebab perbedaan periode fase tersebut bisa diakibatkan oleh faktor nutrien.Vonshak et al. (2004)mengatakan bahwa pertumbuhan sel akan dipengaruhi oleh ketersediaan unsur utama dalamlingkungan kultur yaitu berupa $\mathrm{C}, \mathrm{H}, \mathrm{O}, \mathrm{N}, \mathrm{P}, \mathrm{K}, \mathrm{S}, \mathrm{Ca}, \mathrm{Fe}, \mathrm{Mg}$ dan keberadaan unsur mikro nutrien. 


\section{Konsentrasi Pb pada kultur Spirulana platensis Geitler}

Tabel 1 memperlihatkan bahwa telah terjadi perubahan konsentrasi logam $\mathrm{Pb}$ kecuali pada sel S. platensis pada kontrol yang di awal penelitian tidak dicampurkan $\mathrm{Pb}$. Konsentrasi $\mathrm{Pb}$ di air pada kontrol mengalami perubahan dari $0,002 \mathrm{mg} / \mathrm{l}$ di hari ke-0 menjadi 0,001 dihari ke-7, sedangkan konsentrasi $\mathrm{Pb}$ di sel $S$. platensis tidak mengalami perubahan yaitu tetap sebesar $0,002 \mathrm{mg} / \mathrm{l}$. Logam $\mathrm{Pb}$ yang terkandung pada control merupakan logam $\mathrm{Pb}$ alami yang memang sudah terkandung di air payau sebelum digunakan untuk penelitian, oleh karena itu kandungannya sangat kecil yaitu sebesar 0,002 mg/l. Kadar $\mathrm{Pb}$ alami di dalam air payau sebesar $0,002 \mathrm{mg} / \mathrm{l}$ yang digunakan dalam penelitian masih dalam kategori normal. Arifin et al., (2012) menyatakan bahwa baku mutu logam $\mathrm{Pb}$ yang telah ditetapkan pemerintah dalam air laut sebesar $0,005 \mathrm{mg} / \mathrm{l}$.

Tabel 1.Konsentrasi logam berat $\mathrm{Pb}$ dan jumlah sel $S$. platensis.

\begin{tabular}{lrrrrr}
\hline Hari ke- & Kontrol & $\mathrm{Pb} \mathrm{1mg}$ & $\mathrm{Pb} \mathrm{3mg}$ & $\mathrm{Pb} \mathrm{5mg}$ \\
\hline Hari ke-0 air & 0.002 & 0.949 & 2.894 & 4.88 \\
\hline Hari ke-7 air & 0.001 & 0.603 & 2.46 & 4.31 \\
\hline Hari ke- 0 sel & 0.002 & 0.002 & 0.003 & 0.003 \\
\hline Hari ke-7 sel & 0.002 & 0.342 & 0.431 & 0.549 \\
\hline \multicolumn{2}{c}{ Penurunan Pb hari ke-7 } & $36 \%$ & $15 \%$ & $12 \%$ \\
\hline $\begin{array}{l}\text { Jumlah sel } \\
\text { dihari ke-7 }\end{array}$ & 106.600 & 93.700 & 129.367 & 93.500 \\
\hline
\end{tabular}

Peristiwa penurunan konsentrasi $\mathrm{Pb}$ di air dan kenaikan konsentrasi $\mathrm{Pb}$ di dalam sel, yang terjadi pada perlakuan $\mathrm{Pb} 1 \mathrm{mg}, \mathrm{Pb} 3 \mathrm{mg}$, dan $\mathrm{Pb} 5$ mg menunjukkan bahwa adanya penyerapan $\mathrm{Pb}$ di dalam air oleh sel $S$. platensis. Perez-Rama et al (2002) menyatakan bahwa pada saat pertumbuhan alga berlangsung, logam di lingkungan sel diserap dan diakumulasi di dalam sel, baik secara proses nonmetabolik (adsorption) ataupun metabolik (absorbtion). Selain penyerapan oleh alga, penurunan kadar logam berat juga dapat diakibatkan oleh penguapan dimana logam $\mathrm{Pb}$ terbawa oleh air yang menguap. Penguapan diakibatkan oleh suhu kultur.
Presentase penurunan kadar $\mathrm{Pb}$ masingmasing sebesar $36 \%, 15 \%$, dan $12 \%$. Penelitian yang dilakukan oleh Soeprobowati dan Hariyati (2014) menyatakan bahwa $S$. platensis yang dikultur selama 14 hari ke dalam logam berat mampu menurunkan konsentrasi hingga $88 \%$ pada $\mathrm{Pb}, 85 \%$ pada $\mathrm{Cd}, 89 \%$ pada $\mathrm{Cu}$, dan $88 \%$ pada Cr. Berdasarkan penelitian tersebut maka waktu kultivasi $S$. platensis sebaiknya diperpanjang selama 14 hari untuk meningkatkan persentase penyerapan logam berat.

Penelitian ini menggunakan media air payau, nilai $\mathrm{BCF}$ untuk perlakuan $\mathrm{Pb} 1 \mathrm{mg}, 3 \mathrm{mg}$, dan 5 mg masing-masing 0,$5 ; 0,1$; dan 0,1 . Menurut Chojnackaet al. (2005), proses biosorpsi pada Spirulina sangat dipengaruhi oleh $\mathrm{pH}$. Peningkatan nilai $\mathrm{pH}$ terjadi pada saat penelitian dari 7 menjadi 8 di hari ke-7.Kondisi ini menurut Isnansetyo dan Kurniastuty (1995), masih merupakan kondisi $\mathrm{pH}$ yang ideal bagi pertumbuhan $S$. platensis dan meningkatkan kemampuan serap logam $\mathrm{Pb}$ oleh sel.

Pada gambar 1, perlakuan $\mathrm{Pb} 1 \mathrm{mg}, 3 \mathrm{mg}$, dan $5 \mathrm{mg}$ memasuki fase puncak lebih lama dari kontrol. Perlakuan $\mathrm{Pb} 1 \mathrm{mg}, 3 \mathrm{mg}$, dan $5 \mathrm{mg}$ memasuki fase puncak dihari ke-7, sedangkan Kontrol dihari ke-5. Perbedaan periode mencapai fase puncak tersebut disebabkan oleh keberadaan logam berat di dalam media kultur. Keberadaan $\mathrm{Pb}$ dan $\mathrm{Cd}$ di dalam suatu media akan mengakibatkan pertumbuhan mikroalga menjadi terhambat karena kedua logam tersebut menginduksi aktivitas enzim peroksida yang berperan penting ke dalam degradasi Indolasam asetat (IAA). Hormon IAA adalah hormon yang menstimulasi pertumbuhan dan pembelahan mikroalga (Lamai et al., 2005).

\section{KESIMPULAN}

Berdasarkan hasil penelitian selama 8 hari, $S$. platensis mampu tumbuh pada media air payau yang telah ditambahkan logam berat timbal $(\mathrm{Pb})$. Pertumbuhan kontrol lebih cepat dari perlakuan logam $\mathrm{Pb}$, namun jumlah sel perlakuan logam berat $\mathrm{Pb} 3 \mathrm{mg}$ pada fase puncak $(129.367 \mathrm{sel} / \mathrm{ml})$ lebih banyak dari control (106.600 sel/ml). Hal ini menandakan bahwa logam $\mathrm{Pb}$ pada konsentrasi tertentu $(3 \mathrm{mg} / \mathrm{L})$ memberikan pengaruh pada peningkatan jumlah sel $S$. platensis.Jumlah sel 
pada perlakuan $\mathrm{Pb} 1 \mathrm{mg}$ dan $\mathrm{Pb} 5 \mathrm{mg}$ masingmasing sebanyak $93.700 \mathrm{sel} / \mathrm{ml}$ dan $93.500 \mathrm{sel} / \mathrm{ml}$.

Presentasi penurunan konsentrasi logam berat $\mathrm{Pb}$ dalam media kultur $\mathrm{S}$. platensis antara lain sebesar 36\% (Pb $1 \mathrm{mg}$ ), $15 \%$ (Pb $3 \mathrm{mg}$ ), dan 12\% (Pb $5 \mathrm{mg}$ ). Kontrol memiliki presentasi penurunan logam $\mathrm{Pb}$ sebesar 50\%, namun tidak ditambahkan logam $\mathrm{Pb}$ diawal penelitian.

\section{DAFTAR PUSTAKA}

Aksu, Z \& Donmez, G. 2006. Binary biosorption of cadmium(II) and nickel(II) onto dried Chlorella vulgaris : co-ion effect on monocomponent isotherm parameter. Journal of Process Biochem.

Arifin, B., Deswati, \& Loekman, U. 2012. Analisis kandungan logam $\mathrm{Cd}, \mathrm{Cu}, \mathrm{Cr} \& \mathrm{~Pb}$ dalam air laut di sekitar Perairan Bungus Teluk Kabung Kota Padang. Jurnal Teknik Lingkungan Unand. Padang.

Chojnacka,K., A. Chojnacka, \& H. Gorecka. 2005.Biosorptionof $\mathrm{Cr} 3+, \mathrm{Cd} 2+\& \mathrm{Cu} 2+$ ions by blue-green algae Spirulina sp.: kinetics, equilibrium \& the mechanism of the process. Chemosphere.

Edhy, W.A., Januar, \& Kurniawan. 2003. Plankton di Lingkungan PT. Central Pertiwi Bahari. Laboratorium Central Department. Aquaculture Division PT. Central Pertiwi Bahari. Tulang Bawang.

Hariyati, R. 2008. Pertumbuhan Dan Biomassa Spirulina sp dalam skala Laboratoris. Bioma. Laboratorium Ekologi \& Biosistematik Jurusan Biologi FMIPA. UNDIP. Semarang.

Isnansetyo, A \& Kurniastuty. 1995. Teknik Kultur Phytoplankton Zooplankton Pakan Alam untuk Pembenihan Organism Laut. Kanisius. Yogyakarta.

Lamai C. Kruatrachue M., Pokethitiyook P., Upatham E.S., \& V. Soonthornsarathool. 2005. Toxicity and Accumulation of Lead \& Cadmium in the Filamentous Green Alga Cladophora fracta (O.F. Muller ex Vahl) Kutzing: A Laboratory Study. Science Asia.

Maulana, D. 2013. Pertumbuhan Populasi Mikroalga Spirulina Platensis (Geitler) pada
Konsenterasi Logam Berat Tembaga $(\mathrm{Cu})$ .Skripsi. Semarang.

Mohanty, P., Srivastava, M., \& Krishna, K.B. 1997. The Photosynthetic Apparatus of Spirulina: Electron transport \& Energi Transfer. Di dalam: Vonshak A, editor. Spirulina platensis (Arthrospira): Physiology, Cell-biology \& Biotechnology. Taylor \& Francis Ltd. Bristol, USA.

Naria, E. 2005. Mewaspadai Dampak Bahan Pencemar Timbal $(\mathrm{Pb})$ Di Lingkungan Terhadap Kesehatan. Jurnal Komunikasi Penelitian.

Perez-Rama, M., Alonso, J.A., Lopez, C.H., and Vaamonde, E.T. 2002. Cadmium removal by living cells of the marine microalga Tetraselmis suecica. Bioresour.

Rao, R., Kumar, R., Raghavan, B.G., \& Subramanian, V.V., 2011. Application of phycoremediation technology in the treatment of wastewater from a leatherprocessing chemical manufacturing facility. Department of Plant Biology \& Plant Biotechnology, R.K.M. Vivekananda College. Chennai.

Siswati, N., Tenti I., \& Rahmah, M. 2011. Biosorpsi Logam Berat Plumbum $(\mathrm{Pb})$ Menggunakan Biomassa Phanerochaete chrisosporium. Skripsi. Jurusan Teknik Kimia UPN Veteran. Surabaya.

Soong, P. 1980. Production \& Development of Chlorella \& Spirulina in Taiwan Algal Biomass. Elsevier. Amsterdam.

Soeprobowati, T.R. \& Hariyati, R. 2013. Bioaccumulation of $\mathrm{Pb}, \mathrm{Cd}, \mathrm{Cu}$, and $\mathrm{Cr}$ by Porphyridium cruentum (S.F. Gray) Nägeli. International Journal of Marine Science.

Vonshak, A. S., Boussiba, A. Abeliovich,\& A. Richmond. 2004. Production of Sprirulina platensis biomass: Maintenance of monoalgal culture outdoors. Biotech and Bioengineering.

Widianingsih, Ridho, A., Hartati, R., \& Harmoko. 2008. Kandungan Nutrisi Spirulina platensis yang Dikultur pada Media yang Berbeda. Jurnal Ilmu Kelautan. UNDIP. Semarang. 
